\title{
Notas para uma reinterpretação crítica da erótica weberiana*
}

\section{Artigo Livre Caio Pedron ${ }^{1}$}

* Recebido em 06.05.2020. Aprovado em 21.06.2020

${ }^{1}$ Mestre em Sociologia pelo programa de pós-graduação em sociologia do Instituto de Filosofia e Ciências Humanas da Universidade Estadual de Campinas (IFCH/UNICAMP) e, atualmente, doutorando pela mesma instituição na linha de pesquisa Teoria e Pensamento Sociológico, também participa do grupo de pesquisa Teoria Crítica e Sociologia. Email: caiopedron99@gmail.com.
Resumo: o famoso ensaio Consideração Intermediária guarda uma interessante reflexão sobre a esfera erótica, em especial, sobre o papel redentor desta esfera em um mundo secularizado; ainda que muito lido, poucos foram os esforços empreendidos para trazer à luz os elementos contextuais e intelectuais que enformaram essa reflexão. Este trabalho pretende explorar a ideia de salvação intramundana desenvolvida por Max Weber (1864-1920) em sua esfera erótica, apresentando o seu contexto social de emergência e contrapondo o diagnóstico de tempo - presente nesse escrito - ao desenvolvimento do amor como problema sociológico. Intenta-se, com isso, resgatar os elementos desta reflexão que permanecem válidos para a compreensão do destino social do amor no século XXI, dialogando com algumas teorias sociológicas que pretendem explicar o papel do amor nos tempos do capitalismo.

Palavras-Chave: Erótica, Max Weber, Consideração Intermediária, Contexto, Salvação Intramundana.
Abstract: the famous essay Intermediate Reflection keeps an interesting thought about the erotic sphere, on the redemptive role of this sphere in a secularized world, although widely read, few efforts were made to throw light on the contextual and intellectual elements that shaped this reflection. This work intends to explore the idea of intramundane salvation developed by Max Weber (1864-1920) in his erotic sphere, presenting his emergency social context and contrasting the diagnosis of time - in this writing - with the development of love as a sociological problem. Therewith, the intention is to rescue the elements of this reflection that remain valid for the understanding of the social destiny of love in 21 st century, dialoguing with some sociological theories that intend to explain the role of love in the times of capitalism.

Key Words: Erotic, Max Weber, Intermediate Reflection, Context, Intramundane Salvation. 
2 A rigidez da "forma" através da qual se expressa o pensamento weberiano é bem conhecida e tratada até como escolh pessoal em razão da oposição ao estilo dos eruditos que não levavam a sério ológica do

${ }^{3}$ A mesma passagem da citação acima só que de uma tradução anterior da obra (WEBER, 1984), versão pouco fiel se bem que muito mais poética, como foi fruto de meu primeiro contato com a obra, sinto dizer que me marcou na profundidade de seus versos imperfeitos. Cabe lembrar que, por um paradoxo das consequências, a metáfora mais fo das consequencias, a portáfora mais famos do pensancia resultado de uma tradução pouco segura; contudo, jaula de ferro produz um efeito poético sem igual e serviu aos mais diferentes usos da teoria social até o tempo presente (LÖWY, 2014).

4 Os "especialistas sem espírito e sensualistas sem coração" (WEBER, 2001) formam o tipo de nulidade de espírito que Weber externalizava como espirito que wroma da burocratiza como sendo o probe da burocratização da vida. Em uma de suas intervenções mai polêmicas, Weber criticava o homenzinhos da burocracia estatal que não tinham vontade e nem decisão própria, serviam só para receber ordens e colocá-las em prática. Ver: WEBER, Max. Comentário de Max Weber sobre a burocratização 1909. In: MAYER, J. P. (Jacob Peter). Max Weber e a Política Alemã. Brasília, DF: Editora da UnB, c1985. p.94.

5 Estrutura de personalidade é Eonceito criado por Norbet Elias (1997) que permite pensar a influência do social no comportamento e na forma de ação dos indivíduos. Ela foi usada sob medida para analisar os homens do $2^{\circ}$ Reich em se autoritarismo formalista por sob o qual se "escondia" um alto grau de violência "eprimida, pronta para eclodir a qualquer momento.

\section{Introdução}

Mas do ponto de vista do erotismo esse sentido, juntamente com o conteúdo de valor da relação, repousa na possibilidade de uma comunidade que é sentida como um pleno tornar-se um [wolle Einswerdung], uma vertigem no "tu", uma comunidade tão intensa, que só se explica "simbolicamente": como um sacramento (WEBER, 2016, p.391).

A passagem citada acima condensa boa parte da qualidade poética que encontramos na reflexão que Max Weber (1864-1920) empreendeu no tópico esfera erótica da famosa Consideração Intermediária. É um texto rico em metáforas e sentenças que não coincidem com a rigidez descritiva das páginas que a seguiriam nos Ensaios de Sociologia da Religião, ainda que estes ensaios sejam muito mais agradáveis de se ler quando comparado aos Estudos Sobre Lógica da Ciência ou A “Objetividade” do conhecimento nas ciências sociais ${ }^{2}$

Este trecho, em especial, condensa uma das conclusões de Weber sobre a esfera erótica, é que a sua principal fonte de tensão para com a religião era oriunda do tipo de experiência provocada nos espíritos apaixonados: uma "comunhão experimentada como unificação completa", as vertigens no "tu" que faziam do ato sexual uma celebração do amor quase que sacramental. Essa heresia de Weber pode muito bem parecer um exagero hiperbólico, mas, na verdade, condensa um sentimento comum e coletivo de uma geração que procurava romper com os grilhões impingidos pela moral ascética do período wilheminiano. Era uma resposta frente às frias mãos esqueléticas da razão instrumental e sua febril e fervilhante maquinaria impessoal, resposta aos "homenzinhos" medíocres ${ }^{4}$ que eram formados por esse tipo de estrutura de personalidade ${ }^{5}$ do segundo império.

Mas não é possível, como nos alertou o saudoso ${ }^{6}$ Gunther Roth (1980), estabelecer uma relação (de identidade) “de um para um” entre a biografia e a obra de Max Weber, pois ou se depreciaria a obra em nome de um determinismo - psicológico, social ou histórico - ou, pior ainda, se elevaria a sua obra por sob qualquer contingência da realidade vivida, tornando-a "livre de valor" porque "suspensa" sob a história. É necessário, por isso, separar o que é do dia e o que é da noite, o que é contexto e o que é texto, mesmo que essa separação seja meramente artificial, pois ela consegue nos ajudar a entender a origem social e a singularidade individual de uma ideia ${ }^{7}$.

Tomando o caso de Weber como exemplo, cabe destacar o horizonte comum compartilhado dele e de seus colegas de círculo intelectual que permitiu um meio ideal para o surgimento de um interesse coletivo sobre a erótica, sem hipostasiar, com isso, o caráter de singularidade que a erótica tem, tanto na sua função analítica para o grande quadro desenhado para as religiões mundiais quanto nos aspectos referentes à problemática que o texto encerra em si mesmo. É desta singularidade que a potente crítica de Weber ao erotismo e à comunidade de amor erótico-fraternal pode ser apropriada para que

Dossiê Turismo: entrecruzamentos de cultura, memória e desenvolvimento

Arquivos do CMD, Volume 8, N.1. Jan/Jul 2020 
${ }^{6} \mathrm{Um}$ dos principais comentadores do pensamento weberiano, trazia sofisticação e clareza em todas as suas intervenções sobre o autor. Fica aqui nota de pesar de mais uma referência que nai de vida para entrar para a história que para a história do pensamento social.

Este trabalho expõe os resultados de minha dissertação de mestrado com algumas variações de ênfase que acredito que são pertinentes para tomarmos a esfera erótica como teoria passível de ser utilizada na interpretação do amor como fenômeno social no século XXI. Ver: PEDRON, Caio César. A Gênese Social do Contexto de Emergência da Esfera do Contexto de Emergência da Esfer Erótica Weberiana. Dissertação (Mestrado em Sociologia) Instituto Filosofia e Ciencias Sociais Universidade Estadual de Campinas, Campinas, p.210. 2019.

8 Pequeno livreto de Jessé de Souza (1997) que contém uma reflexão muito poderosa sobre as afinidades e tensões no pensamento de Weber e Habermas. Para Jessé, Habermas abriu mão da ambiguidade constitutiva da crítica à razão instrumental, para abraçar uma construção racional livre dos problemas inerentes ao "sistema". Weber, nesse sentido, conseguiu mensurar o tamanho da tragédia da cultura e entender os limites do desenvolvimento racional frente à dimensão do desaprendido, como pensada por Benjamin.

Referência ao livro de Eva Illouz $O$ amor nos tempos do capitalismo (2011), ele condensa um conjunto de palestras da autora proferida em Frankfurt e tem com objetivo sintetizar as contribuições teóricas da autora em seus trabalhos sobre o desenvolvimento histórico do amor.

Dossiê Turismo: entrecruzamentos de cultura, memória e desenvolvimento

Arquivos do CMD, Volume 8, N.1. Jan/Jul 2020 possamos refletir as consequências do seu diagnóstico frente às patologias da modernidade ${ }^{8}$.

O tom mais ensaístico deste trabalho tem por finalidade dar vazão à liberdade criativa necessária à reinterpretação da esfera erótica e suas implicações para se pensar o amor nos tempos do capitalismo ${ }^{9}$. Não quero dar aqui a resposta final quando se trata de falar sobre este tema, quero, antes, apresentar uma leitura possível e adequada ao nível histórico e de sentido desta teoria que seduz o leitor assim que este lhe dirige o olhar. Aos fortes que conseguirem sobreviver ao canto da medusa, que tenham em mente que este texto é fruto de um interesse engajado em entender o sentido do amor em um mundo desencantado, um relacionamento duradouro e frutífero para com a tese central proposta no ensaio de Weber.

A sequência de concatenação dos capítulos tem o seguinte desenvolvimento: em primeiro lugar, farei uma reconstituição sociológica do papel dos grupos de intelectuais na circulação das ideias e pessoas no período da vida de Weber; depois, apresentarei uma contextualização da teoria das rejeições religiosas do mundo e suas direções, teoria da qual depreende a esfera erótica, que pode ilustrar qual a função analítica deste aporte conceitual na discussão empreendida por Weber no conjunto de ensaios intitulados Ética Econômica das Religiões mundiais; por fim, quero tratar dos conceitos desenvolvidos na esfera erótica à luz do tempo presente, sintetizando as contradições da leitura weberiana e apresentado os possíveis projetos sociológicos que dão continuidade a essa reflexão, seja para sustentar uma crítica a essa concepção de emergência do amor moderno ou para enveredar pela clareira aberta por esse diagnóstico reflexivo.

\section{O Weber-kreis e os movimentos eróticos do início de século}

O círculo de Max Weber se constituiu de maneira mais intensa nos primeiros anos do século XX graças ao esforço de Marianne Weber em organizar as reuniões no antigo solar da família para que o marido - aquela época "inválido"10 - pudesse reencontrar com seus amigos e participar do fluxo de discussões, ideias e personagens que se expressavam nessa forma de sociabilidade comum ao gosto burguês ${ }^{11}$. Do ponto de vista social, Weber estava em uma espécie de situação que podemos chamar de in-betweenness, ou seja, não estava nem dentro das discussões do campo acadêmico e, muito menos, fora, porque continuava a debater com seus amigos e ex-alunos. A revista Archiv für Sozialwissenschaft und Sozialpolitik ${ }^{12}$, da qual era editor, somada aos jours ${ }^{13}$, faziam com que Weber permanecesse ligado aos debates e aos personagens que circulavam pela burguesia de Heidelberg.

Mas o grupo não era apenas um espaço de debate ou de "encontro sofisticado", ele também atendia a diferentes demandas como a dos jovens alunos outsiders ${ }^{14}$ - do qual fazia parte, por exemplo, György Lukács - que procuravam nomeações, indicações 
10 Apenas alguns meses separam a crise psicológica profunda na qual submergiu Max Weber da morte do seu pai (1897) e muitos comentadores, inclusive, tratam o conflito que ambos tiveram pela liberdade da mãe como ato derradeiro do simbólico parricídio freudiano. Após o insucesso em várias tentativas de retomada, Weber retira-se em 1902 dos quadros prefessorais em 1902 dos quadros professorais da Universidade de Heidelberg e passa a desfrutar de uma boa vida sustentando-se através de rendas oriundas da gestão do patrimônio paterno e, também, do patrimônio herdado pela esposa.

${ }^{11}$ Esse tipo de sociabilidade burguesa vivia os seus dias derradeiros e podemos construir um bom quadro de referências para este estilo de vida, tomando, como exemplo, a biografia intelectual de Simmel construída por Leopoldo Waizbort (2000). Nela o autor por Leopo ina Wão (200). Nela 0 autor retraça a cirç o grupo de Simmel e de outros colegas, demonstrando como essa teia de relações amalgamava a burguesia letrada no seu "mundinho pequeno".

12 Periódico refundado em 1904 que teve fundamental importância para a produção do autor, nela foram publicados a maioria dos seus textos, como exemplos: Ética Protestante e "espirito" do Capitalismo; A "Objetividade" do conhecimento nas ciências sociais; Roscher e Knies; Ética Econômica das Religiões Mundiais e, inclusive, a Consideração Intermediária que iremos estudar aqui.

13 Jours é nome que Marianne atribuiu ao encontro do círculo de Max Weber que ocorreu durante todo esse período de recuperação do autor e que, depois de sua morte, retornaria, como forma de homenagem e divulgação dos trabalhos de Max Weber que a autora viria a editar. Ver: WEBER, Marianne, and E. S. "ACADEMIC CONVIVIALITY." Minerva, vol. 15, no. 2, 1977, pp. 214-246. JSTOR, JSTOR, www.jstor.org/stable/41820313.

Dossiê Turismo: entrecruzamentos de cultura, memória e desenvolvimento

Arquivos do CMD, Volume 8, N.1. Jan/Jul 2020 para doutoramento e para vagas no corpo docente da Universidade. Os Webers procuravam auxiliar e estender a mão para todas as pessoas que lhe viessem pedir ajuda e foi através dessas relações que eles puderam conhecer os novos movimentos eróticos, conta-nos Marianne Weber:

Por volta desta época, o núcleo professoral da vida intelectual de Heidelberg recebeu uma grande variedade de estímulos novos, de jovens sem cargo oficial e em todos os estágios de formação, que desejavam entrar no círculo interno acadêmico em algum momento no futuro, ou viver num ambiente intrinsecamente intelectual. As correntes modernas fluíam do exterior para as praias hospitaleiras da pequena cidade. Jovens estabeleciam um novo estilo de vida, além do convencional, junto às estruturas firmemente estabelecidas da geração mai velha. Novos tipos de pessoas, relacionadas aos românticos e seus impulsos intelectuais, mais uma vez, questionavam a validade das normas de ação universalmente obrigatórias, e ou, buscavam uma "lei individual", ou negavam qualquer "lei", para deixa apenas o sentimento influenciar o fluxo da vida (WEBER, 2003, p.426).

O movimento erótico alcançou os ainda jovens acadêmicos de meia idade que se deparavam com uma verdadeira insurreição contrária as normas estipuladas pelo moralismo autoritário típico do espírito prussiano. Esse movimento não apareceu sozinho, inúmeros outros agrupamentos contraculturais emergiram durante esse período, com destaque para a comunidade de Monte Veritá (GREEN, 1986) que serviu como polo aglutinador de diferentes tendências libertárias e progressistas como: os tolstoianos, wagnerianos, teosofistas, vegetarianos, dentre outros. Foi dessa comunidade libertária que se dirigiu para Heidelberg o esteta do amor livre, Otto Gross, com sua técnica revolucionária de superação dos constrangimentos adquiridos através da libertação dos instintos naturais e libidinoso, ou seja, pela liberação sexual.

Gross seduziu boa parte da juventude e, dentre as atingidas por seu poderoso carisma, estava a jovem Else von Richtoffen, aluna de Max e amiga pessoal de Marriane, que havia acabado de se casar com o também aluno e colega Edgar Jaffé. O Weber-Kreis foi atingido em peso pela prédica do profeta do amor, tendo em vista que Else teve um caso com o austríaco, nascendo dessa relação o menino Peter, que recebeu o mesmo nome do filho de Frida Gross que, por sua vez, era amiga muito próxima de Else. Max Weber foi convidado para ser padrinho da criança e não recusou o pedido de sua aluna preferida, no entanto, não deixaria de questionar os métodos e os meios do Dr.X, como podemos ver por sua resposta ${ }^{15}$ a uma carta de Marianne.

Todas essas pessoas estão realmente enredadas numa poderosa teia de grande autoengano, e a sublimação estética destina-se apenas a ocultar-lhes o verdadeiro estado de coisas. O Dr. X não tem necessidades sexuais e vive como polígamo só por "filantropia"? Isso é um disparate. A qualquer um com experiência psicológica nesse campo, basta apenas ouvir essa afirmação sobre a obscenidade do erotismo insatisfeito para saber com o que está lidando (WEBER, 2003, p.439-440).

$\mathrm{O}$ choque entre Weber e Gross era quase que inexorável e embora ambos tivessem posições sociais e geracionais idênticas ${ }^{16}$, suas visões de mundo eram antagônicas e, de algum modo, irreconciliáveis, pois se Weber queria manter a dignidade própria à Burguesia em meio ao 
14 Outsiders porque eram estrangeiros e judeus. Weber tentou ajudar Lukács em seus esforços para conseguir uma nomeação como professor ordinarius - mais baixa categoria professoral - da universidade de Heidelberg. Em um interessante diálogo, Weber relata seu encontro com o famoso filósofo Windelband cujo apoio seria central para nomeação do jovem húngaro, dizia na carta que o professor não havia demonstrado interesse pela pesquisa de Lukács, mas que não demonstrara, também, nenhum preconceito para com sua nacionalidade ou descendência. Ver: LUKÁCS Georg. Georg Lukács: Selected Correspondence: 19021920. Nova York: Columbia University, 1986.

${ }^{15}$ Weber respondia diretamente de Monte Carlo, onde havia ido para jogar nos cassinos da região. Nesse período o autor viajava com frequência e vivia uma vida bastante diferente da até então austera experiência proporcionada pela casa materna e, depois, pela atividade acadêmica.

${ }^{16}$ Creio que a leitura mannheimeana de geração pode ajudar a compreender como um grupo concreto foi influenciado por uma demanda da sua geração sucessora. Gross, de aloum modo, era um predecessor dos movimentos eróticos, atuando como los Weber e Maiane for Weber maria a onda do debate porque pertenciam a essa geração intermediária entre a burguesa que havia se "vendido" aos interesses prussianos e a juventude que não aguentava mais pagar o preço da aliança. Ver: MANNHEIM, Karl. "O problema sociológico das gerações" [tradução: Cláudio Marcondes], In Marialice M. Foracchi (org), Karl Mannheim: Sociologia, São Paulo, Ática, 1982, pp. 6795 caos moderno, defendendo posições progressistas como a liberdade jurídica da mulher e o matrimônio por amor; Gross queria destruir a instituição matrimonial, sintetizando o seu ódio ao patriarcado em uma fórmula revolucionária de combate aos constrangimentos estrangeiros - enxertados na criança através da educação - por meio de uma técnica que libertaria "o próprio" da natureza presente em cada individualidade. Esse processo culminaria na organização social do matriarcado como única forma possível de instituição não opressora (GROSS, 2017)

A juventude se inspirava no movimento de Gross e na imagem soberana de Franciska zu Reventlow, expressão ideal da boemia dos cafés berlinenses, porque via na conduta dessas personalidades um enfrentamento à ordem patriarcal estabelecida, esta que vinha definhando como expressão da condução da vida de uma sociedade alemã em transformação acelerada pelo processo de unificação e industrialização da via prussiana. O que Weber (2015, p.105-106) observava em sua aula inaugural como a crise das classes proprietárias junkers diante da nova configuração econômica - uma classe que não conseguia se sustentar somente pela oferta das commodities produzidas nas quintas ao leste do rio $\mathrm{Elb}^{17}$ - agora se expressava em âmbito cultural. Mas disso deriva uma dúvida, por que as fissuras pareciam maiores na seara do amor, das artes e não em outros campos da experiência humana, como a política, a economia ou o direito? Marianne Weber tinha uma boa resposta:
Esse ataque às tradicionais escalas de valor visava sobretudo à liberalização da moralidade sexual, pois era nessa área que a "lei" e o "dever" exigiam os sacrifícios mais visíveis. Qual era o valor de normas que com tanta frequência sufocava a magnificência da vida vibrante, reprimia os impulsos espontâneos, e acima de tudo negava a realização de tantas mulheres? Lei, dever, ascetismo - não derivavam todas essas ideias da demonização do sexo por um cristianismo exagerado? Modelar o futuro da pessoa inteiramente baseado em sua própria natureza, deixar as correntes da vida fluírem nela e depois aguentar as consequências, era melhor que esgueirar-se furtivamente pelos estéreis caminhos de cautela encurralados pela moralidade (WEBER, 2003, p.427).

Não é que em outros subsistemas sociais não houvesse críticas ou vontade de transformação, mas era na sexualidade que a juventude burguesa se sentia mais tolhida, era ali que ela não podia viver aquela vontade imensa de experimentação dos desejos. $\mathrm{O}$ erotismo primevo prefaciava o fim da era vitoriana e, não sabia ele, que junto com ela o seu reinado também seria destruído. A juventude estava aberta ao novo e pronta para romper com os grilhões que escravizavam o amor às fórmulas prontas do matrimônio, queria "aguentar as consequências" por aquilo que fizera e não se frustrar lembrando do que apenas havia desejado.

O próprio Max Weber, através do contato para com a juventude e com movimento erótico ${ }^{18}$, alterou sua opinião acerca daqueles que incorriam em pequena culpa, cabia aceitar-lhes suas fraquezas contanto que estes não fizessem teorias para legitimar suas falhas morais (WEBER, 2003, p.427). Alguns acreditam que essa mudança

Dossiê Turismo: entrecruzamentos de cultura, memória e desenvolvimento

Arquivos do CMD, Volume 8, N.1. Jan/Jul 2020 
${ }^{17}$ A região ao leste do rio Elba era onde se estabelecera as quintas senhorias do Junkers, a classe proprietária que tinha pode de mando na Alemanha Imperial. Essa propriedades foram estudadas por Max Weber a pedido da Verein für Sozialpolitik e desse trabalho surgiram os insights comentados na aula inaugural de 1894 (WEBER, 2015).

${ }_{18}$ Weber fez algumas incursões à comuna de Monte Veritá, lá esteve assessorando Frieda Gross no caso movido pelo sogro para retirar-lhe a guarda dos filhos. Nesta época, Otto Gross estava internado compulsoriamente em uma clínica e sua esposa vivia com outro homem e Hans Gros aproveitou-se da situação para acusa-la de bigamia - coisa que não era permitida na ainda religiosa lei de matrimônio austríaca perpetrando uma ação para a retirada dos filhos que ela havia tido com Otto Gross. tenha sido fruto dos casos amorosos com Else (RADKAU, 2009; MITZMAN, 1976) e, depois, Mina Tobler, mas outros preferem acreditar que ocorreram mudanças sociais profundas que reorientaram a representação que boa parte dos grupos sociais da burguesia letrada faziam da esfera sexual e, isso sim, acarretou uma mudança na valoração das heterodoxias do amor.

A dura crítica de Weber a Otto Gross (AVIGDOR; SANTOS, 2007) só demonstra a inquietação de alguém que já compreendia a importância dos novos movimentos eróticos, mas não conseguia aceitar a relação que Gross estabelecia entre o exercício científico e a prática revolucionária. $\mathrm{Na}$ concepção weberiana, ciência e prática não podiam se unir a favor de uma visão de mundo sob uma convicção ética própria. Contudo, engana-se quem pensa que a erótica só fazia brilhar os olhos de Max Weber, na verdade, já fazia algum tempo que Simmel (2006) refletia sobre as condições sociais das relações sexuais e, além disso, sobre as possibilidades de experiência do amor abertas para a contemporaneidade:

Natureza erótica? Isto é, uma natureza em que o amor é o a priori interna com outrem? Um a priori tampouco tem por definição aplicar-se a toda matéria. Inúmeras vezes não pensamos causalmente (de maneira correta tácita), o que não impede que a causalidade seja $a$ priori. Pois é apenas se a pensamos assim que pensamos corretamente e compomos o universo teórico com a unidade que ele deve ter. Portanto, a natureza erótica não ama sempre, nem ama todos, mas é na medida em que faz que ela se concentra integralmente e consuma o sentido objetivo de sua vida [...] A natureza erótica enquanto caso limite: $\mathrm{o}$ amor deve definitivamente ir de pessoa inteira à pessoa inteira (SIMMEL, 2006, p.176).

Para Simmel essa natureza não era necessariamente sexualidade, havia naturezas eróticas como Jesus, Espinosa e Francisco de Assis que não eram sexuais. Em Simmel, existem formas de amor e de erótica, elas são pensadas enquanto experiência vital e não como um subsistema social produtor de símbolos, valores e normas que dirigiria a ação dos indivíduos. Simmel havia sido o pioneiro ${ }^{19}$ e, depois dele, Werner Sombart usaria a ideia da importância das relações sexuais e amorosas para o desenvolvimento do capitalismo. Diferente dos dois companheiros, Sombart procura analisar a erótica no campo da economia, ou seja, se tratava de olhar o desenvolvimento do capitalismo não pela ótica da produção, mas pelo consumo, identificando o papel do comércio de luxo para o desenvolvimento do capitalismo. Mas o que o luxo teria a ver com o erotismo?

Todo desejo de refinamento e aumento dos meios adequados para alegrar os sentidos, tem sua última base em nossa vida sexual; o deleite dos sentidos e o erotismo são, no fundo, a mesma coisa (SOMBART, 1958, p.89)

O que significa dizer que, na teoria sombartiana, o desenvolvimento do amor e de sua cultivação durante séculos criou uma demanda por consumo necessária a afirmação do capitalismo. Foram as heteras, coquetes e madames que fizeram com que as "modas" entrassem em vigor e, com elas, todo um circuito comercial de abastecimento de luxo.

Dossiê Turismo: entrecruzamentos de cultura, memória e desenvolvimento

Arquivos do CMD, Volume 8, N.1. Jan/Jul 2020 
${ }^{21}$ Esse foi o nome final dado ao projeto pelo próprio Max Weber, o autor trabalhava no primeiro volume da coleção quando faleceu e a obra continha as versões revisadas da Ética Protestante, Seitas Protestantes, Vobermerkung (Nota Preliminer), Einleitung Vobermerkung (Nota Preliminar), Einleitung (Introdução), Ziswchenbetrachtung Consideração Intermediária) Confucionismo e taoísmo. Esses textos foram revisados e adaptados à grande descoberta de Weber: o processo de racionalização do ocidente (SCHLUCHTER, 1979; PIERUCCI, 2005). ${ }^{22} \mathrm{O}$ que chamamos de secularização, na sociologia da religião, é, antes, um deslocamento do conceito original em Weber, pois para o autor secularização é tão somente a tomada dos bens eclesiásticos pelos Estados em vias de modernização
O interesse pelo fenômeno do erotismo abarcava todo o círculo de Max Weber e podemos encontrar em figuras dispares como Sombart e Simmel expressões e tentativas de interpretação - em teoria social! - da erótica no seu desenvolvimento imanente e na sua expressão entre as individualidades. $\mathrm{O}$ que poderia parecer uma reflexão isolada de um autor é, na verdade, apenas uma das expressões que os círculos burgueses produziram em resposta aos novos tempos dourados prefaciados pela experimentação da juventude burguesa, tempos estes que só não permitiram maiores desventuras porque sua primavera seria mutilada ${ }^{20}$ pela grande guerra.

Havia, portanto, um interesse coletivo pelo sexo na virada do século XX, o freudismo, por exemplo, tornou-se moda em todos os círculos burgueses e o problema da sexualidade infantil rompeu o véu de várias das amarras que o vitorianismo tinha imposto à sexualidade. A geração de 1890 (HUGHES, 1979) abria-se ao irracional e ao inconsciente, ambos os caminhos levavam ao mesmo lugar: ao erotismo, a libido, ao sexo.

Nas próximas páginas desenvolveremos a nossa reflexão através da história do escrito "Consideração Intermediária", identificando sua origem e função para o projeto teórico weberiano e, em um segundo momento, iremos analisar detidamente os elementos que compõem o quadro analítico proposto pelo autor para interpretar o desenvolvimento da erótica como esfera de valor.

\section{A erótica weberiana em seu texto e no seu contexto intelectual}

A) A origem do texto

É impossível entender a função exercida pela esfera erótica e, mais detalhadamente, pela Consideração Intermediária, sem percebela como parte do conjunto geral da obra constituída nos Ensaios de Sociologia da Religião ${ }^{21}$ que, em sua primeira versão publicada como série de textos na Archiv, teve o nome de Ética Econômica das Religiões Mundiais. Esse conjunto de ensaios possui um caráter empírico-experimental onde podemos ver as abstrações tipológico ideais e a construções metodológicas sendo aplicadas a interpretação de fatos históricos. As religiões mundiais passavam por um escrutínio crítico para, por comparação, identificar os elementos que fizeram com que não se desenvolvesse nas sociedades orientais aqueles traços de racionalidade que viriam a conformar o capitalismo.

Se faz necessário, nesse momento, um pequeno parêntese explicativo: a ideia de um processo de racionalização progressivo mas não linear - e que atendia tanto ao continente europeu quanto aos outros continentes é considerada, hoje, a grande descoberta do pensamento weberiano. Alguns autores como Joachim Radkau (2009) atribuem o interesse de Weber pela religião e por esse processo aos vínculos amorosos que estabeleceu no pós-1909, reinterpretando a tese do período dionisíaco (MITZMAN, 1979) da obra de Weber. Penso que a visão do exegeta Wolfgang Schluchter $(1979 ; 1989)$ seja mais convincente a esse respeito, para ele a grande eureka ocorreu por

Dossiê Turismo: entrecruzamentos de cultura, memória e desenvolvimento

Arquivos do CMD, Volume 8, N.1. Jan/Jul 2020 
23 Tradução feita por Parsons da Vorbemerkung e inserida pelo autor na sua tradução da "Ética Protestante", o que deixa o texto completamente deslocado comentando China e Índia em uma obra que só fala de protestantismo. Gosto desse texto e acredito que ele é uma introdução perfeit ao pensamento do autor, sintetiza-se, ali, os objetivos e os caminhos que seriam tomado em sua grande pesquisa sobre religião. Um fato curioso é que muitos autores acreditam, lendo a Vorbemerkung e algumas passagens da Ética Protestante, que Weber já havia "descoberto" o processo de racionalização em 1904, o que é um erro, dado que ess introdução data de 1918-1919 e a "Ética Protestante" que temos nas traduções é fruto da revisão de Weber empreendida para elaboração dos Ensaios de Sociologia da Religião (1918-1920) e não o texto original de 1904 (PIERUCCI, 2005). volta de 1909, menos porque Weber beijou Else von Richttofen nos mares da costa adriática e mais porque os desenvolvimentos ocorridos no círculo de Eranus - grupo de estudo sobre religião do teólogo Gustav Deissmann - permitiram-lhe pensar naquilo que havia tentado destrinchar na Ética Protestante, agora, não como um caso isolado do ocidente, mas como fruto de um processo racionalização universal e que contemplava as esfera da cultura, as ciências, as artes, bem como, a economia e a religião.

Grosso modo, podemos compreender o processo de racionalização a partir da formulação de Antônio Flávio Pierucci (2005), tomando os devidos cuidados para com os limites dessa distinção que é mais didática do que verdadeiramente conceitual, pois o realce extremado da distinção pode substituir o caráter processual e sincrônico dos desenvolvimentos (NOBRE, 2004) por uma hierarquia fixa e imutável. Feita a ressalva, vale o seguinte argumento: a racionalização do mundo é o macroprocesso histórico que coordenar todo o desenvolvimento racional que fora estabelecido pelas civilizações e pode ser mais bem identificado pelas formas religiosas elementares. $\mathrm{O}$ desencantamento do mundo engloba desde a prédica ética e não mágica dos profetas emissários de Israel até o protestantismo ascético, que seria a forma extremada de desmagificação do mundo por uma religião e, em um segundo momento, a esfera de valor intelectual que a religião criou autonomiza-se e seculariza ${ }^{22}$ o mundo mediante as descobertas científicas e o primado da razão sobre a religião.
Portanto, a secularização seria o decurso menor de um processo de desencantamento do mundo que, paulatinamente, racionalizou a experiência vivida dando-lhe um sentido unitário, até que a ciência viesse desvendar a natureza e descobrir o próprio macroprocesso de racionalização do qual faz parte.

Racionalização não é um processo único, mas é uma composição de uma miríade de desenvolvimentos racionais em diferentes âmbitos da cultura e em sentidos e direções, também, distintos. Não existe uma lei única de desenvolvimento de uma racionalidade e, muito menos, uma única direção, ou uma valoração das gradações racionais que colocaria uma sociedade com mais ou menos racional. Weber, inclusive, consegue demonstrar que dentro de uma mesma esfera, em uma mesma sociedade, pode se produzir racionalizações distintas que, a depender do ponto de vista, são racionais ou irracionais.

Por isso, na passagem citada abaixo, veremos que o autor marca - para usar um vocabulário moderno - a sua posição em referência ao que chamará de racionalização, ele faz a comparação entre as diferentes religiões e sociedade partindo do que entende como sendo o racional para a cultura ocidental. Isso significa que, a administração do Estado Chinês, por exemplo, será comparada no que seria racional para a administração pública ocidental. Weber desenvolve melhor:

E porque os interesses capitalista não fizeram o mesmo na Índia ou na China? Por que lá o desenvolvimento

Dossiê Turismo: entrecruzamentos de cultura, memória e desenvolvimento

Arquivos do CMD, Volume 8, N.1. Jan/Jul 2020 
${ }^{24}$ O livro Economia e Sociedade tem duas partes: a Teoria das Categorias Sociológicas e a A economia e as ordens e poderes sociais. A segunda parte corresponde a adjetivação de "velha" porque faz parte de um texto anterior do autor - uma espécie de esboço preliminar - que não havia, até então, sido publicado. Nela constam ainda certas categorias que seriam rearranjadas ou mesmo excluídas do trabalho final. Wolfgang Schluchter (1989) tem um ótimo trabalho que versa sobre essa "composição" estranha e desarmônica do livro final. científico, artístico, político ou econômico não tomou o mesmo caminho de racionalização que é peculiar ao Ocidente? Porque em todos os casos acima o problema é o racionalismo peculiar e específico da cultura ocidental.

Ora, nesses termos é possível entender coisas muito diferente, como a discussão a seguir mostrará repetidamente. Temos, por exemplo, a racionalização da contemplação mística, atitude que, vista de outro prisma, é especialmente irracional, e temos também as racionalizações da vida econômica, da técnica, da pesquisa científica, do treino militar, do direito e da administração. Além disso, cada um desses campos poder ser racionalizado em termos consoantes com valores últimos e finalidades muito diferentes, e o que é racional de certo ponto de vista poderá ser irracional de outro. Racionalizações dos mais variados tipos têm existido em vários setores da vida, em todas as áreas da cultura. Para caracterizar suas diferenças de um ponto de vista da história da cultura é necessário saber quais setores foram racionalizados, e em que direção. Por isso, nossa primeira preocupação é desvendar e explicar a gênese e a peculiaridade do racionalismo ocidental, e po esse enfoque, sua forma moderna (WEBER, 2001, p.32).

A Introdução do Autor ${ }^{23}$ foi escrita para servir como prefácio ou "nota preliminar" em referência a todo o projeto da Ética Econômica das Religiões Mundiais, diferente da Einleitung que é mais circunscrita aos conceitos e tipos ideais aplicados nos estudos empíricos, esse texto versa sobre os objetivos gerais desse empreendimento. A ideia central de Weber era, por meio desse exercício, compreender a singularidade ocidental, só que pelo lado das sociedades que não o desenvolveram, isso se constituía como fator importante para ampliação da tese proposta na Ética Protestante. Carlos Eduardo Sell possui um ótimo esquema conceitual que explica bem as diferenças dos textos produzidos para a sociologia da religião weberiana:

\begin{tabular}{|c|c|}
\hline \multicolumn{2}{|c|}{ Escritos sociológicos-sistemáticos } \\
\hline $\begin{array}{l}\text { Economia e Sociedade } \\
\text { Ensaios Reunidos de } \\
\text { Sociologia da Religião } \\
\text { (GARS) }\end{array}$ & $\begin{array}{l}\text { 1) Religiöse Gemeinschaften } \\
\text { 2) Observação Premiliminar (Vorbemerkung) } \\
\text { 3) Introdução (Einleintung) } \\
\text { 4) Consideração Intermediária: rejeições } \\
\text { religiosas do mundo e suas direções } \\
\text { (Zwischenbetrachtung) } \\
\text { 5) Resultado: Confucionismo e Puritanismo. } \\
\text { 6)O caráter geral da religiosidade asiática. }\end{array}$ \\
\hline & Escritos sociológico-empíricos \\
\hline $\begin{array}{c}\text { Ensaios reunidos de } \\
\text { Sociologia da Religião } \\
\text { (GARS) }\end{array}$ & $\begin{array}{l}\text { 1) A ética protestante e o "espírito" do } \\
\text { capitalismo. } \\
\text { 2) As seitas protestantes e o espírito do } \\
\text { capitalismo. } \\
\text { 3) Confucionismo e Taoísmo. } \\
\text { 4) Hinduísmo e budismo. } \\
\text { 5)O Judaísmo Antigo. }\end{array}$ \\
\hline
\end{tabular}

Tabela 1: Tabela adaptada de (SELL, 2013, p.65).

Essa tabela permite que visualizemos os dois grandes grupos dos quais se constitui a sociologia weberiana madura: os escritos sociológicos sistemáticos e os empíricos. No primeiro grupo temos todas as teorias desenvolvidas para explicar os estudos empíricos da

Dossiê Turismo: entrecruzamentos de cultura, memória e desenvolvimento

Arquivos do CMD, Volume 8, N.1. Jan/Jul 2020 
25 Gosto da distinção feita por Carlos Eduardo Sell (2013, p.278) entre ordem de vida e esfera de valor, a primeira se refere ao nível das ordens sociais, uma espécie de sociologia das instituições definidas que leva em conta a influência do ordenamento na estrutura social e na composição de associações e comunidades. As esferas se referem como centros de distribuição simbólica de valores, ideias e ideais que permitem legitimar a condução da vida de determinados indivíduos, as esferas estariam no nível da cultura. Sell retira essa concepção da distinção feita por Schluchter (2008) do programa weberiano em três níveis: ação, ordem e cultura. Fica aqui uma dúvida, o direito é considerado em Economia e Sociedade como "ordem de vida", mas não aparece na "Consideração Intermediária" como esfera de valor mesmo que boa parte das disputas que ocorram na arena jurídica levem em conta argumentos religiosos; seria interessante se questionar: o direito é uma esfera de valor autônoma ou mera ordem de vida institucional, onde os valores de diferentes esferas se digladiam por legitimidade?
Ética Econômica das Religiões Mundiais e o trabalho tipológico ideal da sociologia da religião da parte velha ${ }^{24}$ de Economia e Sociedade. No segundo grupo temos, apenas, os trabalhos empírico-históricos. Nesse quadro estão excluídos os trabalhos que não versam sobre religião, mas poderíamos inseri-los sob essas duas rubricas sem grandes alterações.

A Consideração Intermediária faz parte dos textos teóricosistemáticos, funciona como uma espécie de quadro através do qual seria possível compreender o processo de secularização das esferas de valor que estava presente na análise desenvolvimental das religiões mundiais. O texto possui uma história particular, tem ao menos três versões (SCHLUCHTER, 1979, p.61), sendo que cada uma delas possui características distintivas, demonstrando um deslocamento com forte ênfase na valorização dessa teoria para o conjunto geral dos ensaios, vejamos cada uma das versões:

1) A primeira versão data de 1913, e não havia sistematizado as "esferas de valor" como subsistemas sociais autônomos e autorreferentes, estava mais próxima de uma colocação da problemática da racionalização do mundo nos múltiplos conflitos que ela provoca entre a religião e o resto da sociedade. Este texto está presente na "parte velha" de Economia e Sociedade, com o nome de Ética Religiosa e “Mundo” (WEBER, 1994, pp.385-403)

2) A segunda versão veio lá pelos idos de 1915, foi publicada na Archiv, já inserida no projeto da Ética Econômica. Recebeu o seu título definitivo, Consideração intermediária: estágios e direções da rejeição religiosas do mundo, e já tomava as diferentes ordens do mundo como esferas de valor. Ganhou, como acréscimo, a constituição da esfera intelectual e a inserção das tipologias da ética da convicção religiosa e da ética da responsabilidade. O texto, nessa versão, já havia ganhado os seus principais elementos.

3) A terceira versão foi escrita entre 1919 e 1920, para a compilação dos Ensaios de Sociologia da Religião e poderia mais bem ser chamada de revisão: o subtítulo ganhou um acréscimo - em negrito - de Teoria dos Estágios... o que fez com que Schluchter (1979) defendesse que haveria um deslocamento positivo de importância do texto original para as duas versões seguintes, que ganharam ênfase e destaque como teoria.

Parece que, conforme Weber foi desenvolvendo sua teoria da racionalização do mundo, o texto da consideração intermediária foi recebendo um maior destaque oriundo de sua função dentro do esquema desenvolvido para explicar o processo de racionalização, tomando por base as religiões mundiais nos seus diferentes caminhos de desenvolvimento. Cabe, agora, uma pequena explicação do que é a Zwischenbetrachtung em sua composição geral.

O texto se constitui, em sua armação, em um arranjo capitular que possui uma introdução geral, explicando as motivações do empreendimento e os limites do instrumento metodológico usado para este estudo e, em um segundo subtópico, Weber apresenta, novamente, a tipologia das vias de salvação - ascese e mística -, pois elas precisam ser encaradas como tipos ideias basilares da explicação;

Dossiê Turismo: entrecruzamentos de cultura, memória e desenvolvimento

Arquivos do CMD, Volume 8, N.1. Jan/Jul 2020 
é que através da relação conflituosa estabelecida entre ordens de vida ${ }^{25}$ e religiões ascéticas e místicas se pode demonstrar o quadro geral das tensões de um mundo secularizado. Após isso, temos as seis esferas sete contando a religião, que não tem subtópico próprio porque está em todos os outros como contraparte - que são: doméstica, econômica, política, estética, erótica e intelectual. Logo depois vem o subtópico dos Estágios da rejeição do mundo, uma espécie de conclusão da discussão ali apresentada e, por fim, As Três forma racionais de teodiceia fecham o conjunto capitular, apresentando uma interessante teoria sobre o desenvolvimento das teodiceias explicação racional do sofrimento no mundo - tomando por base as religiões mundiais.

Portanto, o que vemos é uma teoria que pretende explicar os choques entre as diferentes esferas de valor e a religião ocidental em sua tipificação ascética e mística; a ideia é, realmente, intensificar o conflito para tirar dele, as consequências gerais do choque entre os diferentes subsistemas sociais. Com isso, Weber quer destacar "que em determinados pontos esses conflitos internos são possíveis e "adequados" - mas isso não significa dizer que não haja um ponto de vista a partir do qual se pudesse considera-los "superados" (WEBER 2016, p.362). De posse de um entendimento maior dos pressupostos que envolvem essa teoria, vamos, agora, nos dedicar a exposição pormenorizada da erótica.

B) Decompondo as "peças" constituintes da erótica
A constituição tipológica da erótica enquanto esfera de valor autorreferente possui dois elementos centrais: 1) uma sequência genealógica de desenvolvimento da erótica; 2) uma exposição da tensão naquilo que lhe é elementar. Comecemos pela primeira característica: a erótica esteve por muito tempo ligada à religião, enquanto prevaleciam as doutrinas mágicas do orgiasticismo e as celebrações extáticas e sexuais das religiões tidas como primitivas, ali também, permanecia o espectro do sexo. Porém, o processo de racionalização perpetrado pelas religiões acaba empurrando progressivamente o sexo para o campo da interdição, da violência e do pecado. Essa moralização da sexualidade é o primeiro passo para sua racionalização. Podemos presenciar melhor esse desenvolvimento particular da esfera através de um quadro:

\begin{tabular}{|c|c|c|c|}
\hline Fase de Desenvolvimento & Período & Personalidade & Ação \\
\hline Grécia pré-clássica & $\begin{array}{l}\text { Romantismo de } \\
\text { Cavalaria }\end{array}$ & $\begin{array}{l}\text { Mulher (como bem } \\
\text { material) }\end{array}$ & $\begin{array}{l}\text { Rapto de } \\
\text { Mulheres }\end{array}$ \\
\hline Grécia clássica & Helenismo & $\begin{array}{c}\text { Eromenos } \\
\text { (Jovem ateniense) }\end{array}$ & Pederastia \\
\hline Idade Média & Trovadorismo & $\begin{array}{c}\text { A Dama } \\
\text { (mulher do outro) }\end{array}$ & $\begin{array}{l}\text { Julgamento pelo } \\
\text { olhar }\end{array}$ \\
\hline Idade Moderna & Renascença & Camarada & $\begin{array}{c}\text { Retorno } \\
\text { a brutalidade } \\
\text { masculina }\end{array}$ \\
\hline $\begin{array}{l}\text { Idade } \\
\text { Contemporânea } \\
\text { (Ancient Regime) }\end{array}$ & $\begin{array}{l}\text { Cultura dos } \\
\text { Salões }\end{array}$ & A Dama & $\begin{array}{l}\text { Conversação } \\
\text { interesexual }\end{array}$ \\
\hline
\end{tabular}


26 Aqui eu aplico a ideia de mediador evanescente (JAMESON, 1973) na brilhante tradução de Gabriel Cohn (1979). Ela nos permite pensar na dama como uma figura de transição no constructo teórico/narrativo de Weber, funciona como personalidade "racionalizadora" do erotismo que, apó "racion concretizada a sua racionalização, deixa de existir ou passa a não ter um significado

${ }^{27}$ Aqui está um claro limite do processo de racionalização do erotismo, ele é todo orientado por mulheres, parece que dialoga perfeitamente com a ideia de cultura feminina de Simmel (2006). As mulheres sofisticariam as relações subjetivas e os homens racionalizariam os produtos culturais objetivos; então, no âmbito do amor, a "masculinização" só poderia levar a brutalidade.

\begin{tabular}{|c|lccc|}
\hline 6) & $\begin{array}{l}\text { Idade } \\
\text { Contemporânea } \\
\text { (Modernidade) }\end{array}$ & $\begin{array}{c}\text { Embate intenso } \\
\text { entre religião e } \\
\text { erótica }\end{array}$ & Asceta Vocacional & $\begin{array}{c}\text { Competição } \\
\text { entre valores }\end{array}$ \\
\hline
\end{tabular}

\section{Tabela 2: $\quad$ Adaptado de (PEDRON, 2019).}

Nesse quadro podemos visualizar, sistematicamente, as seis etapas de desenvolvimento da erótica weberiana. Nela encontramos o período, a personalidade e a ação. Quero destacar, nessa discussão, a personalidade - que pode ser também o objeto de desejo - e a ação, que seria o tipo de ação que esse período cristalizou na sua forma. Nos dois primeiros períodos, as personalidades do eromenos e da mulher (esposa grega) tem característica meramente objetal, ambos não são reconhecidos enquanto personalidade autônomas, mas só como objeto de desejo, passíveis de seleção e verificação por parte daquele que os deseja. Mas, quando tratamos da Dama, algo definitivamente muda ela pode ser considerada como um mediador evanescente ${ }^{26}$, uma figura de transição que empoderou o objeto, pois na sua primeira passagem ela insere o julgamento pelo olhar, o que sofistica a erótica e, na segunda passagem, ela apresenta sua ação e a conversação intersexual que orientam o erotismo para os galanteios e para a sedução através da linguagem.

Um ponto necessário de ser comentado é o papel da homossexualidade, ela é, ao mesmo tempo, reconhecida por Weber, mas, de algum modo, dirimida desse papel de sofisticação da sexualidade. Sempre que a homossexualidade aparece, seja no eromenos da Grécia clássica ou no camarada do renascimento, ela está atrelada a uma imagem masculina das relações, que não podiam ser eróticas porque eram brutalizadas ${ }^{27}$. Limites à parte, o que interessa é que existe uma espécie de intensificação das relações eróticas, que não é linear - dado que o retorno à masculinização ou o ascetismo vocacional servem como desvios de orientação que não poderiam ser contados como pontos ascendentes -, mas sim progressiva nos seus desenvolvimentos.

Há uma evolução na importância do papel do matrimônio durante essas etapas de desenvolvimento: primeiro ele é apenas uma forma jurídica de manutenção das posses de um determinado homem, na Grécia helenista a mulher não era valorizada eroticamente, mas somente como um objeto; depois, através da valorização do matrimônio pela igreja católica, a dama - mulher do outro - passa a ser valorizada por estar inacessível, somente ela poderia, se quisesse, flertar através do olhar e consumir o ato do flerte com seu vassalo. Em um período posterior, da cultura de salões, a dama é sofisticada e exige a conversação intersexual através da qual emerge o galanteio e outras formas sublimadas de erotismo.

Podemos pensar nesse desenvolvimento como uma intelectualização do sexo que pode ser orientado tanto de forma ortodoxa quanto heterodoxa ${ }^{28}$. Na formulação ortodoxa se enfatiza o matrimônio e as possibilidades de experimentação sexual e redenção através dele e, na formulação heterodoxa, pensa-se nos tipos de relacionamentos não regulamentados eticamente: casamentos selvagens, amor livre e diferentes outras formas de experimentação da sexualidade moderna. Se, por um lado, a erótica possui esse caráte

Dossiê Turismo: entrecruzamentos de cultura, memória e desenvolvimento

Arquivos do CMD, Volume 8, N.1. Jan/Jul 2020 
28 Essa ideia foi oferecida pelo também estudioso de Weber, Paulo Henrique Rigolin de Moraes. Agradeço a ele pelo cuidado com que leu e criticou o meu trabalho e, também, agradeço aos colegas do grupo de pesquisa Teoria Crítica e Sociologia, através do grupo pude desenvolver os meus conhecimentos sobre teoria social e aprender muito debatendo e criticando os trabalhos al expostos. Deixo aqui meus agradecimentos a todos.

${ }^{29}$ Essa separação entre experiência extracotidiana sexual e intelectualização do sexo não aparece na obra de Weber e se configura como uma interpretação minha que se iniciou na dissertação (PEDRON, 2019), mas se solidificou apenas em reflexões posteriores. Pode ser interpretado, se assim se quiser, como uma distinção didática da contradição inerente a uma esfera de valor autônoma e racionalizada que carrega no seu seio o irracional como potência redentora. racional fruto de seu desenvolvimento em conflito com a religião; por outro lado, esse conflito se amplia e se sustenta a cada fase pelo fato da intensificação da intelectualização do sexo produzir, como contraparte, uma experienciação extra-cotidiana do sexual ${ }^{29}$, aquilo que o autor chamou de salvação intramundana.

Esses dois polos da esfera erótica, que foram desenvolvimentos do processo de racionalização e emancipação da erótica como esfera de valor, podem ser encarados como contraditórios, ou pelo menos conflitivos, pois carregam as duas "faces de jano" do processo: por um lado racional e por outro irracional e, quanto mais racional, mais intenso fica na valorização que essa irracionalidade recebe. É disso que se trata, no fundo, o conflito bási co entre a esfera religiosa e a erótica. Aqui podemos separar esses dois critérios para dizer que o primeiro compete na relação que estabelece com a ascese protestante e o segundo naquilo que carrega de excepcional e que se digladia com a explosão das formas na sublevação mística.

Essa é a segunda parte que definimos no começo desse subcapítulo: o conflito entre erótica e religião, que Weber via como implícito à sua época, era fruto direto do choque da ascese vocacional do puritano com a experimentação do caso extramatrimonial como única forma de libertação do homem de um mundo racionalizado, em suas palavras:

Em meio a essa relação de tensão com o cotidiano racional, a vida sexual tornada extracotidiana e especialmente extramatrimonial pôde aparecer como o único vínculo que ainda ligava à fonte natural de toda vida o ser humano ora em diante completamente solto do ciclo da antiga existência camponesa, simples e orgânica. Vem daí a fortíssima acentuação valorativa dessa específica sensação de redenção intramundana em relação ao racional, a sensação de um abençoado triunfo sobre o racional; a isso se contrapunha, em correspondente radicalismo, a rejeição também inevitavelmente radical proveniente de toda espécie de ética religiosa de salvação extramundana ou supramundana, aos olhos da qual o triunfo do espírito sobre o corpo devia culminar justamente nesse ponto, e a vida sexual não podia representar outra coisa senão o único elo inextirpável com a animalidade (WEBER, 2016, p.390).

Eram mais do que conflitos, concorrências entre formas de significação da realidade amparadas nesse sentimento irracional. A fusão direta das almas representada pela extrapolação de qualquer limite com referência à relevância que uma pessoa tem para com aquela outra e, unicamente para ela, era o mais forte poder intramundano de experimentação de uma sensação salvífica em relação ao tedioso e cotidiano mundo racional. Erótica e estética são esferas de valor que carregam essa possibilidade de ressignificação da existência ${ }^{30}$.

Mas aí, no aspecto mais poderoso e sedutor da esfera erótica, é que reside a contradição que ela esconde: uma dominação muito sofisticada porque querida e desejada pelos parceiros. Aos olhos da religião:

A relação erótica aparece, inevitavelmente, como uma relação de luta, não só nem principalmente por causa do

Dossiê Turismo: entrecruzamentos de cultura, memória e desenvolvimento

Arquivos do CMD, Volume 8, N.1. Jan/Jul 2020 
30 No sentido de um reencantamento da existência, mas de maneira individual, egoísta e efêmera. Tanto na sociologia weberiana quanto na sociologia da religião (weberiana ou não) há um interminável debate sobre a tese do desencantamento do mundo. Naquilo que nos interessa debate No no debate sobre a possibilidade da salvação intramundana reencantar o mundo -, cabe destacar que existem aqueles que como Pierucci (2005) creem nas possibilidades do diabólico poder demasiadamente humano e outros, como Sell (2013), que percebem na própria Consideração Intermediária o antídoto para tal inocente devaneio. Creio que a esfera erótica seja uma resposta interessante para o problema da racionalização no campo da sexualidade, racionalização no campo da sexualidade, contudo, ela está fadada ao contexto no qual Weber estava inserido e a sua visão de mundo que limitou as formas de expressão da heterodoxia (relacionamentos extraconjugais) e permitiu que houvesse conjugação entre dever ético e sexualidade livre apenas no matrimônio por amor, uma ideia extremamente romântica e muito pouco produtiva, se bem que alinhada com tudo que seria produzido pelo romantismo de Hollywood e seus predecessores (ILLOUZ, 2009). ciúme, da vontade de possuir alguém com exclusão de terceiros, mas muito mais, e mais intimamente, porque jamais os próprios parceiros a percebem como tal, a saber: como uma violação da alma do parceiro menos brutal, como um refinado - pois aí se trata da mais humana das entregas de si -, um dissimulado gozo sofisticado de si no outro (WEBER, 2016, 392-393).

Portanto, a salvação intramundana esconde uma dominação muito mais cruel e terrível que aquela produzida pelo líder carismático ou pela tradição, uma imposição de força através do ato de entrega mais humano: o amor. Weber via, portanto, que não havia possibilidade, nem de uma salvação intramundana coletiva e, muito menos, de uma salvação individual, que não fosse um sentimento efêmero. Os laços tendiam ou a se cotidianizar e arrefecer ou a se tornar doentios e violentos; a brutalidade, no final das contas, era a essência através da qual aquela racionalização da sexualidade se fazia independente, assim se configura a relação erótica por três características basilares, ela seria: efêmera, individual e egoísta.

A solução weberiana para o paradoxo da erótica - da liberdade que causa a dominação mais brutal - seria oferecida através de um retorno a valorização do matrimônio como forma de "eticizar" o erótico. A dissemelhança entre a esfera puramente erótica e a instituição matrimonial permitiria um modelo de responsabilidade marital, como pensado por Wiliam Penn, que sustentasse o sentimento amoroso no trajeto da vida humana até o "pianíssimo da velhice". Entretanto, o autor alertava que esse amor era para poucos, pois: "raras vezes a vida o concede puro: aquele a quem for concedido, que fale de fortuna e graça do destino - mas não de "mérito" próprio" (WEBER, 2016, p.395).

\section{Conclusão: o que resta da salvação intramundana no século XXI?}

Com a reconstituição histórica do contexto social de emergência da esfera erótica, bem como, da apresentação do projeto no qual se inseriria a Consideração Intemerdiária, desejei fundamentar a relevância social e individual que conformou a produção da teoria, acredito que não seria possível entender plenamente a esfera erótica sem compreender a que se refere essa tipologia. Ela é uma representação social e responde a interesses científico específicos do tempo e da biografia vivida por Max Weber Fazer uma crítica contemporânea ao conceito sem levar em conta esses fatores seria o mesmo que amputar a teoria da realidade que lhe impregnou, deitando-lhe em um leito de procusto para sair tal qual a figura de Epstein que citamos acima. Por isso, escolhemos o tortuoso caminho de apresentá-la - de uma forma resumida - em sua completude, acredito que, agora, podemos pensar no seu sentido para o tempo presente, após entender que ela reflete um diagnóstico de tempo do passado.

Neste último capítulo pretendo aprofundar e desenvolver algumas ideias que lancei em minha dissertação, mas que não tive fôlego para responder. Serão dois os propósitos principais desta seção, que podem ser apresentados em duas questões: 1) quais seriam as

Dossiê Turismo: entrecruzamentos de cultura, memória e desenvolvimento

Arquivos do CMD, Volume 8, N.1. Jan/Jul 2020 
${ }^{31}$ Foi mais ou menos assim que o professor Josué Pereira da Silva me provocou quando estava em minha qualificação. Sou extremamente grato por essa crítica, acredito que me estimulou a pesquisar várias teorias que serão expostas em próximos trabalhos. Pensar os usos e aplicações de uma teorização que já completou seus 100 anos porizaça que já completou seus 100 ano parece coi produzido no tomando em cont o que foi produzido no campo desde então, podemos encontrar várias correlações de posições e limites da teoria social atual à luz do que foi produzido no século XX. Se voltarmos aos clássicos, poderemos aprender algumas lições importantes sobre sociedade e sobre a concepção de amor, desejo e sexo que mudaram radicalmente desde os primórdios da sociologia.

32 Quando li esse trecho da obra de Sennett, porque é um pequeno capítulo inicial que não é retomado pelo autor na sua narrativa de ascensão e queda do homem público, fiquei pensando principalmente nessa parte da imaginação metafórica que se perdeu se ela não seria resultado da exposição descontinuada do sexo, pois hoje temos desde cedo as revistas (já peças de museus) e os sites de pornografia que estimulam a sexualidade mas não promovem a imaginação. Centrados em si mesmo e estimulados a ver, essa é a tônica da sociedade excitada. Ver: TURCKE, Christoph. Sociedade excitada: filosofia da sensação. Campinas, SP: Editora da UNICAMP, c2010. possibilidades interpretativas que estariam abertas à esfera erótica e quais seriam os elementos que poderiam ser reconstruídos e adaptados ao tempo presente? 2) O diagnóstico weberiano da impossibilidade de uma salvação intramundana - coletiva e duradoura - via erótica pode ser retomado nos dias atuais? Quais os limites e as possibilidades de reconstrução dessa ideia à luz da sociologia do amor? Não pretendo responder à exaustão todas essas indagações, penso que estarei fazendo aqui um inventário de possibilidade de uso e interpretação da esfera erótica, apresentado a agenda de pesquisa que pretendo desenvolver nos próximos anos e uma solução - sempre provisória para os limites que o próprio autor impingiu na estrutura teórica dessa esfera de valor.

A primeira pergunta pode ser resumida a seguinte questão: afinal de contas, para que serve ${ }^{31}$ essa teoria? E creio que a melhor maneira de a responder seria tomando por base os desdobramentos na teoria social recente que poderiam "conversar" com a erótica weberiana. A esfera erótica tem uma relevância história interessante, serve como uma espécie de documento do que se pensava na teoria social sobre o amor nos primeiros decênios do século XX e é possível, através dela, mapear o desenvolvimento da ideias de amor, sexo, erótica e sexualidade, percebendo como a sociologia e os outros campos do conhecimento humano foram reconstituindo sua representação do sexo a partir da realidade imediata e daquilo que a tradição do pensamento os legou.
Aqui a pequena interpretação de Richard Sennett (2015) sobre as tiranias da intimidade aplicada ao amor parece ser frutífera. Interpretar aquele período histórico como um momento de passagem através do qual se operou, em poucas décadas, uma transformação substantiva nas relações de intimidade amorosa não parece de pouca monta; a expansão da intimidade para as esferas do público transformou a erótica, que era uma ação social - traição, violação, impudica, sexo e etc., - em uma expressão acabada do eu, a sexualidade assume aqui como o reverso da moeda e o erotismo perde até mesmo o poder da imaginação $0^{32}$.

Ainda nesse ponto o pensamento de Weber pode ser aproximado ao interessante livro de Eva Illouz chamado $O$ Consumo da Utopia Romântica (2009), através da comparação podemos encontrar linhas de desenvolvimento entre a genealogia apresentada por Weber e aquela que é exibida pela autora. Se, para Weber, o erotismo havia alcançado o ápice da tensão com a religião na virada do século XIX para o XX, para Illouz essa tensão seria menor diante da romantização da vida produzida pelo cinema a partir dos anos vinte, exatamente o período seguinte ao que o autor havia desenhado. A autora cita um interessante trabalho do sociólogo Herbert Blumer ${ }^{33}$, a serviço do escritório de educação dos Estados Unidos, no qual o autor apresentava o efeito dos filmes de Hollywood sobre a juventude norte americana: através dos filmes eles aprendiam a seduzir, encantar e beijar. Deriva dessa construção uma nova forma de subjetivação da

Dossiê Turismo: entrecruzamentos de cultura, memória e desenvolvimento Arquivos do CMD, Volume 8, N.1. Jan/Jul 2020 
${ }^{33}$ O livro faz parte de uma coletânea de pesquisas encomendadas pelo Estado e nos apresenta, através de entrevistas, a opinião dos jovens sobre sua "formação sexual" através do cinema. $\mathrm{O}$ interessante é que os Estados Unidos foi a nação puritana por excelência, fundada pelo pacto do Mayflower e cuja sociedade se rendeu ao amor romântico do cinema de maneira contundente.

34 Agradeço imensamente ao professor Michel Nicolau por essa provocaço na

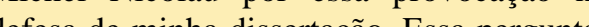
defesa de ninha dissertação. Essa pergunta, que se desdobra em outras tantas, me acompanhou durante os últimos meses e, as reflexões que seguem, são produto desse exercício intelectual.

35 Duas jovens cometeram suicídio na comuna e foram ajudadas por Otto Gross ele ofereceu-lhes veneno. Gross era reconhecido como representante dos relacionamentos livres dentro da comunidade e, por isso, sua imagem e suas am ainda mais manchadas por deias ficaram ainda mais manchadas po esse trágico envolvimento erótica que superou - ou esqueceu - as tensões com a religião e, no entanto, se conectou definitivamente ao capitalismo.

Mudando de assunto, poderíamos pensar na relação entre as esferas de valor, mais propriamente entre o amor e a esfera econômica. Nesse aspecto, poderíamos tratar a teoria weberiana como um modelo macroteórico de explicação das relações entre os subsistemas sociais e apontar os polos de contradição que não estão presentes em sua obra Um bom caminho para desenvolver essa reflexão seria através de um diálogo com o trabalho de Viviana Zelizer (2005), a autora dialoga exatamente dentro desse "hiato" entre as relações pessoais e afetivas e as relações comerciais e impessoais, trabalhando nas imediações dos tipos ideias construídos pela economia para demonstrar que, na realidade, toda transação econômica pode e é mediada por relações de proximidade. Isso não significa negar a racionalização econômica e o primado da transação impessoal do dinheiro na vida, mas é demonstrar que existem negociações, lutas e trocas econômicas que não podem ser explicadas apenas por um conceito abstrato. Nenhuma "robinsonada" pode explicar como se geriam os conflitos pessoais e econômicos através do direito.

Outra possibilidade analítica é a de assumir a ideia das esferas de valor como subsistemas sociais e contrapor às interpretações "bourdiesianas" que, em anos recentes, apresentaram teorias que pretendem dialogar nas imediações desses diferentes subsistemas Catherine Hakim (2012), por exemplo, montou uma teoria do capital erótico, este que seria, para a autora, um capital negligenciado e desvalorizado porque é um monopólio do gênero feminino. Contrapor essa leitura perigosa da erótica com a visão weberiana e a de Eva Illouz (2011) permitiria uma leitura genuína da proximidade entre a teoria dos capitais simbólicos de Bourdieu e as esferas de valor weberianas, isso porque ajudaria no entendimento da erótica como um conjunto de práticas, comportamentos, estilos de vida e valores possíveis de gradação hierárquica e que, em diferentes contextos, teriam diferentes graus de legitimação social. O fenômeno que ganhou notoriedade recente, no Brasil, chamado de relacionamento sugar, seria um bom objeto para se pensar esse capital erótico nas intersecções entre amor e troca mercantil, por exemplo: como se estabelecem esses vínculos, quais as regras que os legitimam, qual estilo de vida e visão de mundo é proporcionada para aqueles que a experimentam?

A segunda questão - das possibilidades de redenção intramundana - é bastante capciosa e, nessas páginas finais da conclusão, pretendo respondê-la com alguma objetividade e não apenas à título de inventário para excurso futuro. O caráter redentor da sexualidade permanece vivo? Quais suas possibilidades reais de produzir essa salvação e que tipo de salvação seria essa? ${ }^{34}$ Primeiro cabe aqui apontar para os limites do pensamento do próprio autor, Weber aposta todas as suas fichas contra a salvação intramudana que não fosse na e pela ordem, ou seja, que não fosse ortodoxa, seguindo os preceitos de um matrimônio eticamente regulamentado. Perdoar os que incorreram em pequena culpa está muito longe de compreender a

Dossiê Turismo: entrecruzamentos de cultura, memória e desenvolvimento

Arquivos do CMD, Volume 8, N.1. Jan/Jul 2020 
36 Penso aqui na conceituação mannheimeana, me parece que ela é útil para entender essa leitura enviesada - da determinação ideológica do pensamento da burguesia letrada - por outros termos que ñ̃o só o morlisor oúpico tenos que não só o nuón burguesa. Ele não explica, por exemplo, como a geração seguinte, que também experimentou esse moralismo, não teve nenhuma afinidade para com ele ao ponto de querer libertar-se dessas amarras. singularidade dos relacionamentos amorosos heterodoxos e o que eles poderiam produzir como formas de relação amorosa não opressoras.

Ao visitar a comunidade de Monte Veritá (WEBER, 1999), Weber não procurou compreender as relações de amor livre que tentaram se estabelecer pela primeira vez naquela localidade, talvez, o trágico resultado dos esforços paranoicos de Gross ${ }^{35}$ tenham-lhe "fechado a cabeça" para outras formas de relação amorosa que não fossem marcadas pela polarização matrimonial/extramatrimonial. Essa é a chave que aponta definitivamente para o limite do pensamento do próprio autor, ao questionar a erótica ele reduziu-a a uma polarização que era fruto de sua visão das relações amorosas:

Por isso, seria possível pensar com o aparelho tipológico da esfera erótica em um novo estágio de desenvolvimento no qual a luta se daria não nas relações entre matrimônio regulamentado pela religião e pelo direito; mas sim, no choque entre as relações eróticas fechadas - matrimônio e relações extraconjugais - e as abertas - poliamor relacionamentos abertos, comunidades de vida erótica - o que abriria o campo de discussão das possibilidades de redenção intramundanas. Isso, porque, ao conceber somente as relações eróticas fechadas como formas válidas de relacionamento sexual, Weber acabou constituindo a sua crítica aos limites do relacionamento entre dois indivíduos, no caso os amantes, que não tinham escolha a não ser a do "gozo sofisticado de si no outro"; enquanto que, poderia mudar muito, se aceitasse como possível uma relação sexual com a participação de um número maior de pessoas (PEDRON, 2019, p.176 - negritos do autor)
Pensar que Weber estava, novamente, em um momento de transição na própria lógica conflitual da esfera erótica pode fazer, agora, muito mais sentido. Isso porque, a tônica do choque entre ascese e necessidade reprimida extravasada em atos conjugais não poderia ser bem explicada pelo comportamento da primeira juventude transviada, ou do Dr. Gross. Olhando com certa acuidade para a realidade histórica, seria possível afirmar que a geração de Weber via com seus olhos - e com visão natural e pré-constituída de mundo ${ }^{36}$ um fenômeno da geração precedente que estaria rompendo os limites impostos pelo patriarcado Junker no campo da sexualidade.

Seria possível pensar, através dessa releitura do conceito de esfera erótica, núcleos de resistência contra hegemônicas, localidades onde houvesse resistência a racionalização que tenderia a pasteurizar a erótica aos beijos de um Burt Lancaster e de uma Deborah Kerr no escurinho do cinema. Então a salvação intramundana poderia estar resguardada nas heterodoxias eróticas? A isso Marcuse (1975) responderia negativamente: a perversão, mesmo quando tomada como única válvula de escape à racionalização do cálculo que tudo uniformizava, só poderia, como princípio de emancipação, destinar os homens para viver em uma sociedade de maníacos sexuais (MARCUSE, 1975, p.176). Mas esse limite que a heterodoxia parecia impor ao capitalismo está há muito superado, hoje um gigantesco mercado erótico de fetiches, bondages, dildos e outros prazeres perigosos se impõe mesmo em referência a perversão. Resta, então, 
nos resignarmos diante da difícil realidade da extensão mercadológica para todas as esferas da vida?

Como é possível que essa crença no amor permaneça como eixo fundamental da experiência sentimental das pessoas, se ele só sintetiza o fracasso em se encontrar uma esfera da vida não racionalizada e que reconecte o homem com determinado elo perdido de si mesmo? Seria o vício, a vontade de possessão violenta e o estímulo incessante que a indústria cultural produziu, fazendo-nos projetar na vida dos astros as nossas miseras vontades libidinais, que nos levaram a esse estado de coisas? Pode ser que sim, mas, também, pode ser que o amor tenha se racionalizado e se tornado, talvez, hegemônico como forma de significação maior da realidade existente.

É isso que os Beck (2017) propõe quando assumem que a luta não é mais de classe, mas sim entre os sexos, que mesmo lutando por suas emancipações financeira, política e pessoal, não conseguem deixar de viver juntos - ou separar-se - só para, depois, voltar a viver outro amor. Sendo que a leveza tão procurada e proclamada em cada pedaço de relação acabaria por se tornar o insustentável fardo que será rejeitado em nome do próximo amor.

A crença no amor é a não tradição, a pós-tradição, porque escapa às características clássicas, não necessita institucionalização nem codificação nem legitimidade para se tornar e permanecer subjetiva e culturalment eficaz. Ela surge, antes, na interação com a, e da sexualidade liberta, destabuizada, com a erosão cultura profunda da atribuição óbvia de papéis. Em conformidade com a estrutura social moderna, nenhuma autoridade moral externa é responsável pelo amor, apenas o entendimento entre os próprios amantes. Enquanto a fé, que não é mais ensinada, se desintegra, o amor é uma "religião" sem Igreja e sem sacerdotes, cuja existência é tão certa quanto a força gravitacional da sexualidade destradicionalizada. (BECK;BECKGERNSHEIM, 2017, 199).

Portanto, ao mesmo tempo que a erótica "perde" suas características emancipatórias, ela se torna mais e mais central para significação individual das pessoas. Uma "religião terrena do amor" que prescinde de tradição e instituição, que está nas mãos dos próprios amantes e que só depende deles para vigorar.

Essa liberdade também pode produzir violação e violência, pois as regras estabelecidas entre as partes podem se dissolver e, os outrora amantes, se tornam com muita facilidade os amargos ex(s). As regras do relacionamento são pactuadas e repactuadas dentro da própria relação à dois e, por isso, não há juiz externo que possa lhes dizer o caminho certo a seguir.

Essa tal liberdade é, também, uma janela de oportunidades, pois ela permite uma autonomia para a ação muito maior do que a de períodos predecessores e sua racionalização terapêutica do sexo, que começou com Freud, permitiu que as pessoas externalizassem suas tensões, que tivessem um código comum compartilhado para tratar dos problemas no relacionamento e que pudessem dialogar com um profissional sobre a saúde da relação. Uma complicação que não é de todo ruim, como Eva Illouz (2011) demonstra apresentando-nos esse mercado de autoajuda e terapia que não pode ser reduzido a mera fetichização da subjetividade tornada mercadoria. Ele pode ser,

Dossiê Turismo: entrecruzamentos de cultura, memória e desenvolvimento

Arquivos do CMD, Volume 8, N.1. Jan/Jul 2020 
também, uma possibilidade real para se criar narrativas e diálogos sobre a condição humana dentro das relações amorosas.

Talvez o tipo de redenção produzida pela sociedade atual não seja o carismático poder libertador do sexo, mas o reconhecimento do outro, não como objeto de dominação ou como meio para o gozo sofisticado de si, mas como coparticipe de uma relação destinado ao afeto mútuo, ou seja, a responsabilidade ética que Weber previra como única forma de racionalização valorativa do amor, pode ocorrer, não através do matrimônio, mas sim através de relacionamentos livres e conscientes de suas limitações e fraquezas. Não seria possível, então, produzir essas ilhas de racionalidade substantiva, de experimentação e liberdade em meio ao caos totalmente normal do amor?

Termino esse raciocínio com mais perguntas que respostas. A erótica em Weber não salva e a possibilidade aberta pelas relações heterodoxas foi mercantilizada e vendida em cinquenta tons de cinza. Portanto, deve-se recolher os cacos do sonho e da possibilidade de salvação intramundana nos moldes pretendidos pela geração de 1890 e, também, pela de 1960. Mas, talvez, essa captura do amor, possua algo de positivo, porque, se levarmos a sério a ideia de que ele possui algo de irracionalizável, de excepcional e extra-cotidiano, então saberemos que mesmo em condições sociais mercantilizadas o amor pode significar algo para além delas. Em uma sociedade que permite uma liberdade maior de ação, esse amor poderia promover relações mais humanas, coletivas, duradouras e generosas.
Talvez a salvação intramundana esteja só a um passo da concretização real; talvez ela já seja experimentada por várias pessoas em movimentos e relações especiais e significativas sob o signo da unicidade e da contingência; talvez seja uma questão de olhar para as condições sociais estabelecidas e criar - dentro e fora de seus limites - as possibilidades de redenção intramundana no aqui e no agora.

\section{Referências}

AVIGDOR, R. SANTOS, Y. (2005). Carta a Else Jaffé de 13 de setembro de 1907, de Max Weber. Plural - Revista De Ciências Sociais, 12, 123-132. https://doi.org/10.11606/issn.21768099.pcso.2005.75675.

BECK, Ulrich; BECK-GERNSHEIM. O caos Totalmente Normal do Amor. Petrópolis: Vozes, 2017.

BLUMER, Herbert. Movies and Conduct. Motion Picture and Youth colection [The Payne Funds Studies]. New York: Macmillan Company, 1933.

COHN, Gabriel. Crítica e Resignação: fundamentos da sociologia de Max Weber. São Paulo: T.A Queiroz, 1979.

ELIAS, Norbert. Os alemães: a luta pelo poder e a evolução do habitus nos seculos XIX e XX. Rio de Janeiro, RJ: Jorge Zahar, 1997.

GIDDENS, Anthony. A transformação da intimidade: sexualidade, amor e erotismo nas sociedades modernas. São Paulo, SP: UNESP, c1992.

Dossiê Turismo: entrecruzamentos de cultura, memória e desenvolvimento

Arquivos do CMD, Volume 8, N.1. Jan/Jul 2020 
GREEN, Martin Burgess. Mountain of Truth: the counterculture begins, Ascona, 1900-1920. Hanover, N.H.: Tufts University: University Press of New England, 1986.

HAKIM, Catherine. Capital erótico: pessoas atraentes são mais bemsucedidas. A ciência garante. Rio de Janeiro, RJ: Best Business, 2012

HUGHES, H. Stuart. Consciousness and society: the reorientation of European social thought 1890-1930. Brighton: Harvester Sussex, c1979.

ILLOUZ, Eva. El consumo de la utopía romántica: el amor y las contradicciones culturales del capitalismo. Buenos Aires: Katz Editores, 2009.

ILLOUZ, Eva. O Amor nos Tempos do Capitalismo. Rio de Janeiro, RJ: Zahar, 2011

JAMESON, Fredric. "The Vanishing Mediator: Narrative Structure in Max Weber." New German Critique, no. 1, 1973, pp. 52-

89. Disponível em: JSTOR, www.jstor.org/stable/487630. Accesso em 19/06/2020.

LÖWY, Michael. A Jaula de Aço: Max Weber e o marxismo weberiano. Tradução de Mariana Echalar. São Paulo, SP: Boitempo, 2014.

LUKÁCS Giörgy. Georg Lukács: Selected Correspondence: $1902-$ 1920. Nova York: Columbia University, 1986.

NOBRE, Renarde Freire. O desencantamento do mundo: todos os passos de um conceito. Rev. bras. Ci. Soc., São Paulo, v.19, n. 54, p. 161-164, Feb. 2004.

MARCUSE, Herbert. Eros e Civilização: uma interpretação filosófica do pensamento de Freud. Rio de Janeiro: Zahar, 1981.
MITZMAN, Arthur. La jaula de hierro: una interpretacion historica de Max Weber. Coautoria de Max Weber. Madrid: Alianza, c1976.

PEDRON, Caio César. A Gênese Social do Contexto de Emergência da Esfera Erótica Weberiana. Dissertação (Mestrado em Sociologia) Instituto de Filosofia e Ciências Sociais da Universidade Estadual de Campinas, Campinas, p.210. 2019.

PEDRON, Caio César. Salvação Intramundana pela Perversão? Sobre a possibilidade emancipatória através da esfera erótica de Max Weber in: QUERIDO, F.M. (et al.). Teorias Críticas entre passado e presente, Coleção Ideias; IFCH, 2019.

PIERUCCI, Antônio Flávio. O Desencantamento do Mundo: todos os passos do conceito em Max Weber. 2. ed. São Paulo, SP: USP: Editora 34, 2005.

PIERUCCI, Antônio Flávio. Secularização em Max Weber: Da contemporânea serventia de voltarmos a acessar aquele velho sentido. Rev. bras. Ci. Soc., São Paulo, v. 13, n. 37, p. 43-73, June, 1998.

PIERUCCI, Antônio Flávio. Eleição 2010: desmoralização eleitoral do moralismo religioso. Novos estud. - CEBRAP [online]. 2011, n.89 [cited 2020-06-20], pp.6-15. Available from:

$<$ http://www.scielo.br/scielo.php?script=sci_arttext\&pid=S0101-

$33002011000100001 \& \operatorname{lng}=\mathrm{en} \& \mathrm{nrm}=\mathrm{iso}>$. ISSN 0101-

3300. https://doi.org/10.1590/S0101-33002011000100001.

RADKAU, Joachim. Max Weber: a biography. Tradução de Patrick Camiller. Cambridge U.K.: Polity, c2009.

ROTH, Gunther. Part A. Ideological Conflit and Scholarly Commitment. In: BENDIX, Reinhard. Scholarship and partisanship: essays on Max Weber. Coautoria de Guenther Roth. Berkeley, CA: Univ. of California, 1980. 
SELL, Carlos Eduardo Max Weber e a Racionalização da Vida. Petrópolis: Vozes, 2013.

SCHLUCHTER, Wolfgang. Acción, Orden y Cultura: estúdios para un programa de investigación en conexión con Max Weber. Buenos Aires: Prometeo libros, 2008

SCHLUCHTER, Wolfgang. The Paradox of Rationalization: On the Relation of Ethics and World. In: ROTH, Guenter; SCHLUCHTER, Wolfgang. Max Weber Visions of History. University of California 1979 .

SCHLUCHTER, Wolfgang. Economy and Society: The End of a Myth. In: SCHLUCHTER, Wolfgang. Rationalism, Religion and Domination: A Weberian Perspective. University of California Press, 1989

SIMMEL, Georg. Filosofia do Amor. 3. ed. São Paulo, SP: Martins Fontes, 2006.

SOMBART, Werner. Lujo y Capitalismo. Guilherme Davalos Editor, 1958.

TURCKE, Christoph. Sociedade Excitada: filosofia da sensação. Campinas, SP: Editora da UNICAMP, c2010.

WAIZBORT, Leopoldo. As Aventuras de Georg Simmel. São Paulo, SP: Editora 34, 2000.

WEBER, Marianne, and E. S. "ACADEMIC CONVIVIALITY.” Minerva, vol. 15, no. 2, 1977, pp. 214 246. JSTOR, JSTOR, www.jstor.org/stable/41820313.

WEBER, Max. Escritos Políticos. [Coleção Folha. Grandes nomes do pensamento v.19], São Paulo: Folha de S.Paulo. 2015.
Letters from Ascona. In: WHIMSTER, Sam (org.). Max Weber and the culture of anarchy. Coautoria de Sam Whimster. Houndmills, Basinstoke, Hampshire: Palgrave Macmillan, 1999.

WEBER, Max. Comentário de Max Weber sobre a burocratização 1909. In: MAYER, J. P. (Jacob Peter). Max Weber e a política alemã. Brasília, DF: Editora da UnB, c1985. p.94.

ZELIZER, Viviana A. Rotman. The purchase of intimacy. Princeton, NJ: Princeton University Press, c2005. 